\title{
小児大腿骨頸部骨折の治療経験
}

\author{
熊本赤十字病院整形外科 \\ 桃 崎 和 彦・平良誠 \\ 川島重明・錦戸崇久 \\ 山内達朗・松永保英
}

\section{Treatment of Fractures of the Neck of the Femur in Children}

by

\author{
Kazuhiko Momosaki, Makoto Taira, Shigeaki Kawashima \\ Takahisa Nishikido, Tatsuro Yamauchi \\ and Yasuhide Matsunaga \\ Orthopedic Surgery, Kumamoto Red Cross Hospital.
}

\begin{abstract}
The results of the treatment of six children with fractures of the neck of the femur are reviewed. Three cases were Type-II fractures and three were Type-III fractures. Four of the six cases had displaced fractures and from these, two cases with displaced Type-II fractures underwent an operation for open reduction and internal fixation. The other four cases were treated with skeletal traction or plaster spica casts. Four cases achieved good results, one fair, but the other one was poor. This poor result was due to other traumatic injuries. One Type-II fracture had avrscular necrosis and premature epiphyseal closure. Coxa vara was found in two of the cases with displaced fractures. We think, undisplaced Type-II and Type-III fractures are best treated with conservative therapy.
\end{abstract}

\section{は じめに}

大腿骨頸部骨折は高令者によくみられる骨折である が，小児においては稀な骨折の1つである，本骨折は 一般的な小览骨折の特性が通用しにくいとと，骨頭壊 死をはじめとする合併症の発生などいくつかの問題点 をかかえている. 今回われわれは，当院で経験した小 児大腿骨頸部骨折について検討したので文献的考察を 加えて報告する.

\section{症例}

昭和 50 年 5 月より 59 年 3 月までに当院で治療した 小児大腿骨頸部骨折は 7 例である.乙れは大腿頸部骨 折患者総数 182 例 の $3.8 \%$ にあたる. 受傷時年令は 10 力月より 8 才までで平均 5 才 2 力月である。受傷 原因は交通事故によるもの 4 例，ブランコ遊歔中のむ
の 2 例で, 交通事故による 4 例のうち 2 例に他部位の 骨折之臟器損傷を，他の 2 例飞も他部位の骨折を認 め, 強力な外力により発生したと考えられた.

骨折の分類は Delbet-Colonna によるものが一 般的で Type I (transepiphyseal), Type II (transcervical), Type III (cervicotrochanteric), Type IV (pertrochanteric) の4型にわけら れる. それによると Type II 3 例, Type III 3 例, Type IV 1 例であった. 保存的治療で整復位の 得られなかった Type II の2 例に観血的治療を行な い，他の 5 例は保存的に治療した. 受傷後 1 年以上経 過した 6 例を, 疼痛, 可動域, 活動性, X線所見によ る Ratliff の基準により評価すると，Good 4 例， Fair 1例, Poor 1例であった. 又, 合併症として 1 例飞骨頭壊死亡骨端線早期閉鎖を，2 例に内反股を 認めた。 


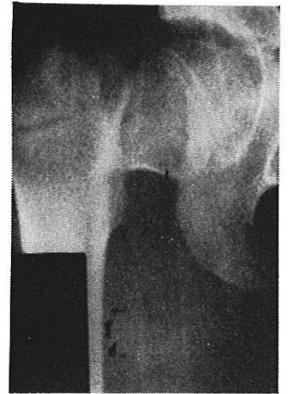

受傷待

Type IIの骨折で転位 高度である

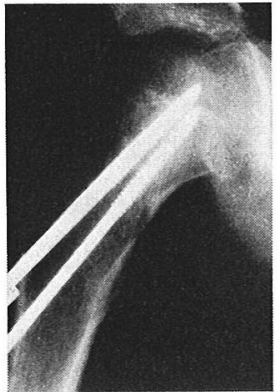

術直後

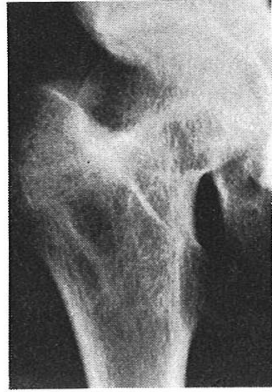

術後 4 年 4 力月 骨頭変形と莖部の短縮 を認める

図 1 症例 1

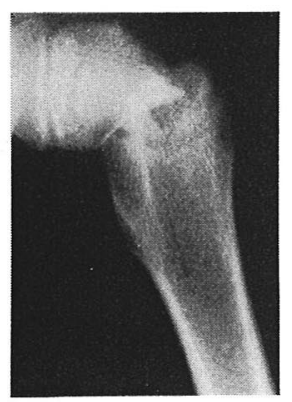

受傷時

Type IIの骨折で転位 高度である

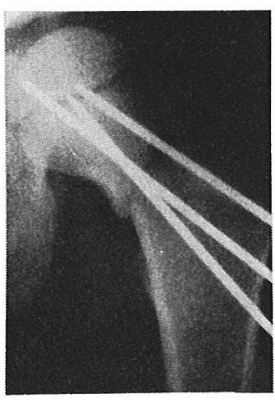

術直後

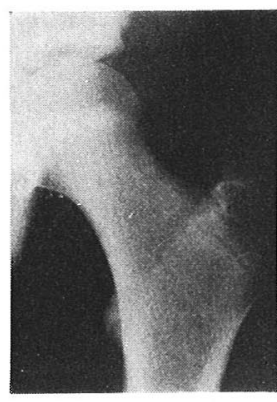

術後 5 年 7 力月 軽度の内反股を認める

図 2 症 例 2

症例 1：8才男子で交通事故により受傷した Type II の骨折で仙腸関節離開と下腿骨骨折を合併 していた．保存的に整復位が得られず Knowles pin による観血的整復固定を行ない, 術後 10 力月時の $\mathrm{X}$ 線にて骨頭の一部に不整像を認めた. 4 年 4 力月後の X線にて骨端線早期閉鎖による形部短縮を認め, 疼痛 なく可動域も良好であるが 軽度の 跛行を 呈する（図 1).

症例 2:6才女子でブランコが左股関節部にあたり 受傷した Type II の骨折である. 保存的に整復され ず, Kirschner wire による観血的整復固定を行な う. 5 年 7 汃後の $X$ 線にて 軽度 の内反股を認める が, 臨床上問題はない（図 2).

症例 $3 ： 5$ 才女子で交通事故により受傷した Type II の骨折で，骨盤骨折を合併していた，牽引 后ギプス固定を行なう， 2 年 4 か力後のX線は良好で

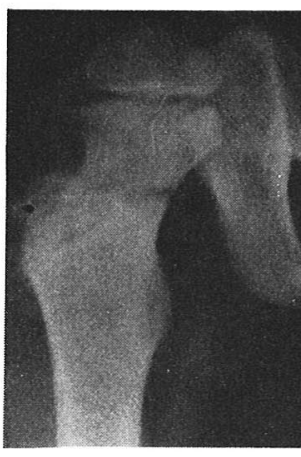

受傷封

Type III の骨折で転位は ない

図 3 症例 3

臨床上も問題はない（図 3 )。

症例 4：7才女子で箱型ブランコの下敷きになり受 


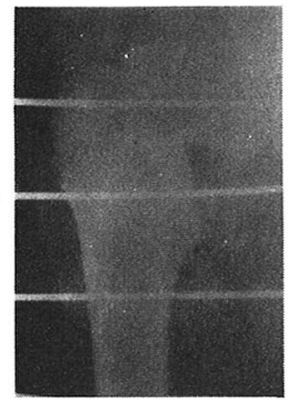

受傷獎

Type IVの骨折で転位 高度である

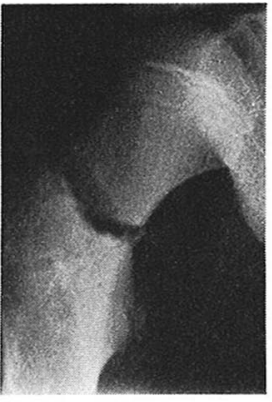

率引後

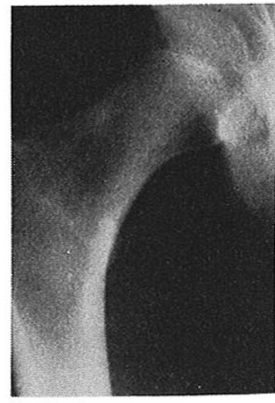

受傷後 7 年 7 力月

内反股を認める

図 4 症 例 4

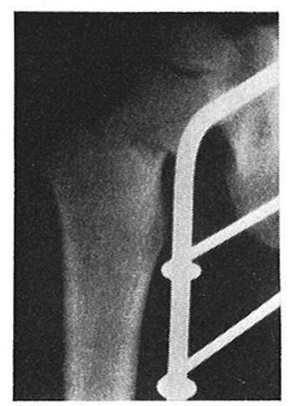

受傷時

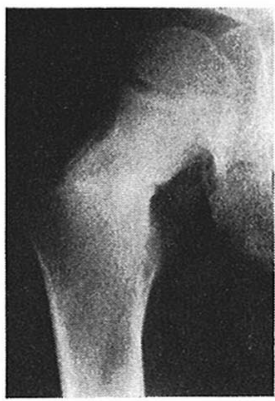

受傷後 2 力月

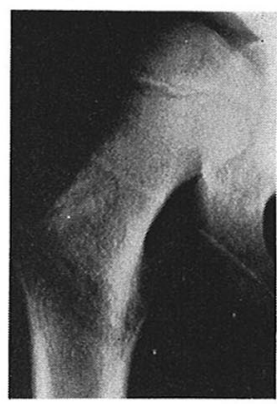

受傷後 2 年 9 力月

Type IIIの骨折で転位 軽度である

図 5 症例 5

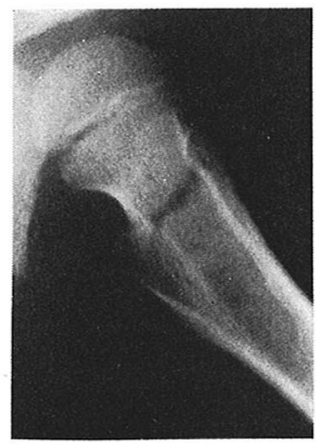

受傷洔
Type IIIの骨折で転位は ない

図 6 症例 6

傷した Type III の骨折である. 率引後ギプス 固定 を行ない， 2 か月後荷重開始した. 7 年 7 か月後のX 線で内反股を認めるが臨床上問題ない（図 4).
症例 5：2才女子で交通事故により受傷した Type III の骨折で, 膀胱破裂, 骨盤骨折を合併していた. ギプス固定により治療し， 2 年 9 か月後のX線は良好 で臨床上も問題ない（図 5 ).

症例 6:5才女子で交通事故により受傷した Type III の骨折で, 尿道断裂，骨盤骨折，同側大腿 骨顆上骨折, 同側足部の高度挫隇創, 両慰部加ら両大 腿部にわたる広範囲皮虞剝脱創を合併していた．左下 腿切断後ギプス固定を行なった. 下腿義足使用のため の活動性の低下と植皮後の皮虞性拘縮による可動域制 限あり成績は Poor であるが, 1 年 6 か月後のX線 は良好である（図6）。

$$
\text { 考擦 }
$$

小児の大腿骨頸部骨折は一般の小児骨折と異なり， その機能的予後が不良となるものが多く治療困難な骨 折の 1 つである，その原因として，発生頻度が少ない 
表 1-a Type II の 症 例

\begin{tabular}{c|c|c|c|c|c|c|c|c|c}
\hline \hline No. & 年 齢 & 転 位 & 治 療 法 & 免荷期間 & 成 績 & 骨頭壞死 & 内反股 & 偽関節 \\
\hline 1
\end{tabular}

表 1-b Type III の 症 例

\begin{tabular}{c|c|c|c|c|c|c|c|c}
\hline \hline No. & 年 齢 & 転 位 & 治 療 法 & 免荷期間 & 成 績 & 骨頭壊死 & 内反股 & 偽関節 \\
\hline 4
\end{tabular}

ため治療法が確立されておらず，安易な方法がとられ うるととや骨頭壊死，内反股，偽関節，骨端線早期閉 鎖といった合併症の発生があげられる，骨頭壊死は最 あ予後を左右する因子であるが，その発生率は文献的 飞 $40 \%$ 前後とかなり高率にみられる，その発生は骨 折部位により明らかに異なる一方，治療法に関係なく みられるととより, 坂巻は受傷時にある程度決ってい るあのであると述べている.

内反股が保存的治療例に多いというととは諸家の報 告で一致しており，整復位の不十分と不適当な外固定 がその理由としてあげられている．McDougall は骨 瘁合後の頸部の可撓性を指摘しており，斉藤は早期荷 重も内反股の一因であろうと述べている. 症例 4 は内 固定の適応であり，荷重開始時期も早すぎたと考えて いる.

偽関節の発生頻度は Canale によれば $6.5 \%$, Ingram $12.5 \%$ あ゙あが，渡辺の本邦例の集計では 28 例中 1 例之少ない，伊藤は保存的治療中に転位高 度となる場合をのぞけば，癒合を得られないととは少 ないとのべている.

骨端線早期閉鎖を Ratliff は骨頭壊死の初期の所見 であると述べており，坂巻は骨頭壊死症例の 70 80 \%に本現象をともなうと述べている，その結果下肢短 縮が大きな問題となる. 症例 1 では $1.5 \mathrm{~cm}$ の脚長差 があり，軽度ではあるが跛行の原因となっている.

本骨折の治療では，以上述べてきた様な合併症の発 生を最小限にすることが重要であり，正確な整復位の 獲得とその保持をできるだけ atraumatic に行なう ととが必要である。その方法には骨折型, 転位の有 無，年令を考慮すべきである．
Type I の骨折は骨頭壊死の発生頻度が高いが, 岩 崎は低年令での骨頭壊死は，骨頭自体の remodeling は良好で，転位した epiphysis の atraumatic な整 復と Kirschner wire による内固定を行なうと述べ ている. 坂巻は頸部軸之骨端線の角度が $20^{\circ}$ 以下を 固定許容角とし，乙れ以上の転位のある場合整復を行 なうとしている。

Type II, Type III の骨折は保存的治療を行なう か内固定を行なうかで意見がわかれている．Lam は 転位の程度と年令で治療プランをたてて扔り，転位の ない場合はギプス固定，転位のある時は 8 才以下に は徒手整復后ギプス 固定, 8 才以上には徒手整復後 pinning を行なうとしている。岩崎は Type II, Type III の骨折の半数は観血的整復操作が必要で, 整復位の保持にギプス固定は不適であるとして内固定 の必要性を主張している. 坂巻は Type II と転位あ る Type III に内固定を行なうが, 血流温存の立場 から整復不能の場合も open reduction は好ましく ないとのべている.

自験例では転位高度の Type II の骨折は, 率引や 徒手整復で全く整復位が得られず観血的整復を必要と し，転位高度の Type III の骨折は牽引后ギプス固定 で内反股を残したことから，現在われわれは次の様に 考えている、転位のある骨折はできるだけ atrau一 matic 飞整復後内固定を行なう，転位のない骨折は 牽引後ギプス固定を行なう。転位のない骨折は整復位 の維持が困難ではないようであり, また鶴見, 岩崎が 頸部䯣内血行の 意義の 重要性を示唆していることよ り，まずは保存的治療を選択すべきと思われる.

Type IV の骨折は一般的に予後良好で, 毫引後ギ 
プス固定でよいと思われる。しかし，まれに骨頭壊死 や内反股の発生をみることがあり注意を要する.

$$
\text { ま と め }
$$

当院にて治療した小児大腿骨頸部骨折について検討 し文献的考察を試み以下の様な結論を得た.

1）整復位の保持が十分であれば骨癒合は良好であ る.

2) Type I 及び転位ある Type II, Type III の 骨折は内固定の適応と考元る。

3) 転位のない Type II, Type III 及び Type IV の骨折はまず保存的に治療を行ない，その方法之 して牽引後ギプス固定が適当である.

\section{文献}

1) Canale, S. T.: Fracture of the neck and intertrochanteric region of the femur in children. J. Bone Joint Surg., 59-A: 431443, 1977.

2) Ingram. A. J. et al.: Fractures of the Hip in children. J. Bone Joint Surg., 35A : 867-887: 1953.

3）伊藤晴夫ほか：小児の大腿骨頸部骨折の治療. 災害医学，21：845-852，1978。

4）岩崎勝郎活加：小児に招ける大腿骨頸部骨折の 治療上の問題点. Hip Joint，8：16-23，1982.
5）忽那龍雄ほか：小览の外傷性股関節脱臼およ び股関節周辺の骨折. 災害医学, 16: 727-734, 1973.

6) Lam, S. F : Treatment of Fractures the neck of the femur in children: Orthopedic, clinics of North America. 7: No. 3, 625-632, 1976.

7) McDougall, A.: Fracture of the neck of Femur in childhood: J. Bone Joint Surg., 43-B : 16-28: 1961.

8) Ratliff, A. H. C.: Fractures of the neck of the Femur in children, J. Bone Joint Surg., 44-B : 528-542, 1962.

9）齐藤勝活加：小児大腿骨頸部内側骨折の 5 症 例. 災害医学, 21：645-649，1978.

10）坂巻豊教ほ加：小児の大腿骨頸部骨折. 整形外 科MOOK，13: 175-186, 1980.

11）鶴海寛治ほ加：小巟大腿骨頸部骨折. 整形外 科, 13: 284-290, 1962.

12）渡讱誠ほ加：若年者大腿骨頸部骨折の経験. 関 東整災誌，4：29-35，1973.

\section{解 答熊本赤十字病院 桃崎 和彦 \\ 固定材料について}

キルシナー鋼線の様な径の細いものが良いが，安定 性の得られないあの, 年長児には Knowles pin を 使用する. 